\title{
Teaching and learning practical subjects in primary schools in Swaziland: The case of a school in the Hhohho region
}

\author{
Sithulisiwe Bhebhe and Zodwa Gcinaphi Nxumalo \\ Faculty of Education: University of Swaziland, Swaziland Corresponding author:Sithulisiwe Bhebhe
}

\begin{abstract}
This study sought to examine the teaching and learning of practical subjects in primary schools. The main focus of this study was how the practical subjects are taught in one school in the Hhohho region of Swaziland. The study examined the experiences and perceptions of learners and teachers. A qualitative approach case study research design in which one-on-one interviews and observations were used to collect data was used. Data were analysed for content and conclusions were drawn. The main conclusions of the study were that practical subjects are timetabled to be taught in primary schools. The study also concluded that practical subjects sharpen the brains of the learners. The main findings of the study were that practical subjects are essential in the holistic development of the learner. It was also a finding in this study that most teachers and learners have a positive attitude towards practical subjects albeit that some teachers lacked confidence in teaching the subjects. The study recommends that teachers be assisted through workshops and short courses to boost their confidence in teaching practical subjects. The study also recommends that policies be put to place in order to ensure that practical subjects are taught in primary schools.
\end{abstract}

Key words: Practical subjects; primary schools; teaching and learning; teachers; learners

\section{BACKGROUND TO THE STUDY}

Practical subjects are vital in the development of a learner's brain, mind, and soul, and therefore should be made compulsory for learners (Earl, 2013). This should be done so that the learners acquire skills that will make them not want to seek employment (The Herald, 2013). In Swaziland primary schools, practical subjects are anessential part of the curriculum. Through the teaching and learning of practical subjects learners acquire skills and knowledge in practical work. Some of the practical subjects taught at primary school are Agriculture, Physical Education, Practical Arts, Needle-work and Consumer Sciences. These subjects are a preparation for the occupational lives of the learners since the recipients are equipped with skills to face the challenges of the world of work. The primary school course in Swaziland consist of seven levels starting from grade one up to grade seven. However, some learners begin their formal education in grade zero (kindergarten) and some do not as it is not compulsory. Third world countries face challenges in implementing practical subjects in the curriculum (Warni, 2014; Waithera, 2013. The researchers in this study felt that as a third world country Swaziland may not be an exception. Swaziland has found it necessary to continuously review the education system to make it relevant to the local needs of the learners and this includes the teaching of practical subjects. To ensure this there has been an inseparable relationship between education, curriculum and national goals. Whatever was included in the curriculum had to be relevant to the needs of the society. A number of countries in Africa, at their independence from the colonial rule, saw and used the school as an important instrument to achieve their political aims and to foster particular attitudes and values deemed necessary for national achievement and cultural identity. Swaziland is no exception as the same thing was done after independence in 1968 (Domson-Lindsay, 2014). The Imbokodvo National Movement (1972) states that all education shall be designed to inculcate love of our land, loyalty to our king and country, self-respect, self-discipline, respect for the law accompanied by the highest degree of knowledge and the building of character. In Swaziland, education is regarded as a critical capable sector of transforming society, and the introduction of practical subjects was seen as a valuable move (The National Committee Education Report (NEC), 1975). This was done to change attitudes towards practical subjects since most people had a negative attitude towards them. These subjects were aimed at developing the learners' intellectual, moral, aesthetic, emotional, physical and practical capabilities that are needed to shape and adapt to the fast changing complex and uncertain socio-economic environment. Formal education was introduced to Swaziland in 1902 and was designed to provide education for the European children in this British Colony (NEC, 1975; Domson-Lindasy, 2014). This kind of education was modeled on the segregationist system developed in the Transvaal province in South Africa. By 1916 governmentmaintained schools for European children had been founded and by 1920, free and compulsory education was available to all white children. The education of Swazi children, which never became free and compulsory under the British rule, remained primarily the domain of the various Christian Missions in Swaziland who established 
the first native school around 1900. By 1924, some 17 per cent of school-age Swazi children were attending missionary and government- controlled schools where literary education was only provided as it was perceived to be useful for Swazi children (Domson-Lindsay, 2014). The emphasis was on agriculture and manual training. In 1963, as the kingdom of Swaziland was approaching independence, it saw as one of its goals the evolution of a non- racial society. The racially segregated education system which had been developed in South Africa was rejected and a racially inter-grated school system was implemented. According to Booth (2004) by 1965, there was manual labour and an increased emphasis on Arithmetic, English, Zulu and other academic subjects in the syllabi for both primary and secondary education in Swaziland. This was done to meet an independent Swaziland's need for a trained labour force, which included specialised workers. After Independence in 1968, the goal of the new government was to attain universal primary education by 1985 (Booth, 2004). In 1975 the Nation Education Commission set new guidelines stating that education should reflect Swazi life and custom and that the emphasis should not be solely on academic subjects, but also on the practical subjects. During the 1990s the Swaziland Ministry of Education proposed a nine year basic education program that included 'practical subjects' such as Agriculture, Home Science, Technical subjects, and Commercial studies. Currently, there are proposals being made to increase the diversity of the curriculum at the senior secondary school level and increase the number of practical subjects in order to support a larger agricultural programme (NECORM, 1985). Today, in a country where the literacy rate is between 70 and 80 per cent, the debate continues over the relevance of the changes which might need to be made to the present education system. The National Education Review Commission (NECORM, 1985) states that Swazis saw the need to develop practical arts education. The secondary level education needed future expansion that would meet the manpower requirements and employment opportunities. There was a need to move away from the narrow academic education oriented to the Cambridge school certificate to a programme that will be in keeping with the reality of the student future life. The NECORM(1985) therefore recommended that practical subjects be included in the curriculum in order to prepare the learners to participate fully in industrial, agricultural and community development. The NERCOM (1985) also recommended that the school programme be diversified to include practical, occupational subjects like Agriculture, Home Economics, Elementary Technology and Technical Trade Skills. It further put forward that admission to vocational education should not be based on examination certificates but on the talent of the child. In line with this The Ministry of Education had to develop a coherent policy for the strengthening and expanding of Practical subjects which include Agriculture, Technical/ Vocational subjects, Commercial subjects, Home Economics and others. This was to be done taking into consideration the regional distribution of facilities, adaptation of curricula, rationalization of resources, teacher education and other related factors (NEC, 1975). In the first two years of the proposed four years of secondary education, besides the core subjects, pupils had to also do the basic practical subjects which are Agriculture, Technical subjects, commercial subjects and Home Economics. The National Education Review Commission (1985) also reports that the Ministry of Education further introduced pre-vocational practical arts, technical agriculture and Home Economics as an alternative or an equivalent to $\mathrm{O}$ ' level in high school practical arts education and was to be strengthened by providing pre -vocational facilities at high school and constructing new regional vocational training centres (V.T.Cs). It was put forward that at the latest, by the end of the second year of secondary school, through the use of aptitude tests and continuous assessment, student more technically oriented should be streamed into prevocational practical programmes. It was also put forward that examinations at the end of the four years of secondary school be equivalent to internationally accepted levels of proficiency for the practical arts stream and they should aim at maintaining high standards, record adequate prestige, and value, thus ensuring that certain fields or disciplines are not viewed as inferior or as less prestigious than others. To strengthen the teaching of practical arts there was a provision for advanced studies for graduates of the practical arts stream which was made through the Vocational Training Centres, Swaziland College of Technology and University preparatory courses. The NECORM (1985) further introduced the development of technical and vocational teacher education which was vital for practical arts teaching. This was done by expanding facilities at the Swaziland College of Technology and use of qualified people in different vocational occupations as teachers or instructors. The Ministry Education also saw the need to enact the Industry and vocational Training Board Act of 1982 which established the Industry and Vocational Training Board. The Act also talks of the formal establishment of trade committees to guide the standard of training and the operation of the scheme. It also established the director of the Industry of Vocational and Training under the Ministry of Education whose job was to coordinate training efforts by the various training institutions and regulate fund collection disbursed from the training levy. UNESCO (2006) also saw the need for practical arts to be taught from the earliest stage or primary education. The land civilization patterns was to be re-adjusted so that land could be made available to school leavers training in agriculture and that such school leavers be given financial assistance to establish themselves as well as market their products. There was also a need to set aside some government farms to be used for training the youth in modern agricultural methods and in setting up agricultural cooperatives. This was done after the realization that vocational/ practical education is a vital tool an individual can use to be developed for 
employment as it involves training for employment in trades like, industries, agriculture, business and home making which can prepare one for self-reliance. It is in the light of this that the American Vocational Association (1971) sees vocational subjects as those designed to develop skills, abilities, understanding, attitude, work habit and appreciation encompassing knowledge and information needed for any worker to enter and make progress in employment on a useful and productive basis. It contributes to the production of good citizens by developing their physical, social, civic, cultural and economic competencies. While other countries support vocational training and the introduction of practical subjects, the advent of formal education in Nigeria neglects vocational and practical education entirely. Despite all efforts made to recognize it, little or no attention was given to it. For a long time no meaningful development was made in the area of vocational education until 1981, when the National policy on Education was published. Due to this total neglect, vocational education suffered a major decline in quality, number, policy and directive in Nigeria due to the total neglect. It was after the oil boom era 1970s that it dawned on the nation that there was acute scarcity of skilled manpower (The Nation online Net, 2012).Bell (1989) argues that Federal Government wants vocational/technical education to occupy a prominent position in their secondary schools. Nigerian schools pay little or no attention to vocational/technical subjects. Teachers and students seem not to understand what it is all about and consequently, develop contempt and aversion for the subjects. As such vocational/technical subjects remain unhealthy. Many of the occupations and trades are regarded as ignoble and unbecoming. An average Nigerian parent does not want his son to earn a living as a full time farmer, a watch-repairer, a plumber, a house painter because for many Nigerians, these jobs are for the poor and underprivileged. Padunmg (1994) stresses that typically the higher the occupational status of the students' parents, the positive their attitude towards science. This is to say that higher occupational parents would want their children to be doctors, engineers, etc. without considering if the child would actually learn science subjects to achieve that. The influence of parents in the development of student's interest in vocational/technical subjects cannot be over emphasized because parents seem to have a big influence on their children's choice of educational careers. The socio-economic status of parents of a child determines the type of career one chooses to do. Some parents have biased and rigid thoughts regarding the occupational choices of a child/children. Parents forget that every type of work, once it is beneficial to the individual and society, is worthy and noble, (Nwankwo, 1998). The result of this is a quasi-calculated attempt to frustrate the good intention of the federal and state government about vocation/technical education. The quality sign of potential success in students' vocational pursuits requires the identification of the student's interest, aptitudes, abilities, values and judgments, if these will be discovered. It requires a guidance counselor who will give the appropriate occupational information to the student with proper exposition to various opportunities available in the world of work. Studies reveal that many parents are not interested in vocational/practical subjects. Osuala (2001) opines that, at the heart of our society and economic problem is a national attitude that implies that vocational/technical subjects are designed for somebody else's children and is meant primarily for the children of the poor. This same attitude is shared by students. Thus, it makes the students lack interest in the study of practical subjects' particularly Home economics. The term practical/vocational education is defined differently by different people. Masri (2000) emphasises that the term either practical or vocational education has no single universally accepted definition but what is common is the various definitions, its goals and objectives that remain the same. Practical education has been defined as that phase of education which seeks to help the people, students and the populace acquire specific mechanical or manipulative skills required in industrial arts or applied sciences. The national policy on education (2004) states that the goals and objectives of vocational and technical education are to provide trained manpower in applied science, technology and commerce in particular at sub-professional grades, provide technical knowledge and vocational skills necessary for agriculture, industries, commercial and economic development, give training and impact the necessary skills leading to the production for craft-man, technicians and other skilled personnel who will be enterprising and self-reliance to enable our young men and women to have intelligent understanding of the increasing complexity of technology and to give an introduction to professional studies in engineering and other technologies.Leedy (2001) reports that occupational areas within which vocational and technical educational subjects fall largely into are: Agriculture, Home economics, Business and mechanics, practical Arts. However, Agriculture and carpentry remain improper choices because they do not attract much interest amongst the students. Masri (2000) emphasises that Home economics is a unique and dynamic field of study. Its central theme is the improvement of lives of individuals and a field of study that draws knowledge from many disciplines including science and humanities in order to fulfil its objectives. Being a vocational subject that focuses on the welfare of individuals, families and societies, Home economics contributes meaningfully to the solutions of the problems of the society such as unemployment, poverty, malnutrition (Ducci, 1991).Leedy (2001) also stresses that Home economics as a vocational subject is required to equip the learner with the knowledge of skills and attitudes necessary for the effective management of the home. It requires skills, wisdom, dedication, care, intelligence, unusual patience and a very strong power of observation and imagination. Therefore, in order for a student to have these qualities there is need to study vocational/ technical subjects and as this is done teachers have to ensure that they teach 
these subjects effectively for learners to benefit. In order to effectively teach practical subjects teachers need to be trained so that they can have the required skills. This is because the greatest single factor in teaching and learning is the teacher (Dlamini, 2011). No technique, no method, no device, no gadget can guarantee success, but only an effective qualified teacher can adequately execute the requirements of the subject (Dlamini, 2011). Thus the greatest motivating device yet discovered is a highly motivated teacher and learners who are actively involved in the teaching and learning process. The skills that teachers possess in teaching can influence the student enrolment and motivation in vocational/practical subjects. This is because the method of teaching/approach is very vital in any teaching/learning situation (Cohen, 1994). The way the teacher presents the subject matter to the learner may make a student like or dislike a subject. Ducci (1991) further points out the need for blending theoretical and practical work in teaching learners to stimulate students' interest more especially on vocation/ practical subjects. Practical subjects are very useful in teaching and learning because both the teacher and the learner are involved in the process. The learners are able to develop individual abilities because practical subjects grant them more freedom to practically do the work themselves. Furthermore, they have more opportunities to develop special and unique talents (Haggerty, 1999). Practical subjects make the learners to be independent in life and to be able to take their own decisions and rely on them. Learners find it easier to assimilate matter which is set out (Cooke, 2001). Practical subjects also make both the teacher and the learner to develop confidence. They bring freedom in teaching and learning which makes it to be enjoyable (Camara, 1997). Through becoming involved in the teaching/learning situation, investigating, and also in making discoveries for oneself, the learners' sight is widened. Again learners realise their potential and feel secured in the learning process and their self-concept is strengthened (Giddens, 2006). Lahey (2004) postulates that practical subjects take education as the practice of freedom, as they help the learners to perceive things critically the way they exist. In doing practical subjects Masri, (2000)reveals that education should ensure that students are actively involved and given the responsibility for practical solutions for practical problems. Cohen (1998) concurs with Masri (2000) that education should be a preparation for life where learners should be taught in such a way that they understand problems and solve them in practical ways in their context. Pragmatists also agree that involving students in practicals and experiments gives them the best experience. Cohen (1989) adds that education should serve everyone and not just a chosen few. He therefore also advocates for practical subjects in schools. He believes that education should produce individuals who are self-reliant. This therefore renders practical subjects imperative in the process of teaching and learning hence teachers and learners should value practical subjects.

\section{The main research question of the study}

What is the perception of teachers and learners about practical subjects taught in primary schools in the Hhohho region of Swaziland?

\section{Research Objectives}

The objectives of the study were to:

(a) Establish teacher's perceptions towards practical subjects.

(b) Identify challenges faced by teachers when teaching practical subjects.

\section{Research Methodology}

The study utilized the qualitative approach where the case study research design was employed. Leedy (2001) postulates that the case study is especially suitable for learning more about a little known or poorly understood situation. It further investigates how an individual or program changes over time. Cohen (2000) argues that the case study is of a small group, a single, or a specific case. The qualitative approach is primarily exploratory research. It is used to gain an understanding of underlying reasons, options, and motivations. Furthermore, qualitative research is also used to uncover trends in thoughts and opinions, and dives deeper into the problem (Leedy, 2001).The data collected in qualitative research depends on human experience and this is more compelling and powerful than data gathered through quantitative research. In qualitative research issues and subjects covered can be evaluated in depth and in detail. Qualitative data in this study were gathered from few individuals, hence, the findings and outcomes of the study were not spread to larger populations but could be used to similar cases. The use of the qualitative approach in this study enabled the researchers to describe the variable that was studied and further find out the perceptions of both teachers and learners about practical subjects.

\section{Research instruments}

Research instruments are data gathering instruments used to obtain information from which to draw valid conclusions (Leedy2001). The research instruments that were used in this study are observations and interviews. Chiromo (2009) posits that observations seek to ascertain what people think and do by watching 
them in action as they express themselves in various situations and activities. The observer can be part of the population. This allows the observer to collect powerful and meaningful data. In this study the researchers were part of the school community in the Hhohho region of Swaziland when the research was done. One-on-one interviews were also used to collect data in this study. According to Mushoriwa (2009) an interview is a data collection technique that involves oral questioning of the respondents either individually or as a group. Interviews can also be viewed as a conversation between an interviewer and interviewees with the purpose of obtaining relevant information (Mushoriwa, 2010). Cohen and Manion (2002) define an interview as a conversation carried out with the definite purpose of obtaining certain information and it is designed to gather valid and reliable information through the responses of the interview to a planned sequence of questions. During interviews responses may be recorded or quoted verbatim. Interviews allow the researcher to get understanding of peoples', perceptions and behaviour through body language. In this study the researchers used semistructured interviews. Nkambule (2011) states that semi-structured interviews are used to ensure that the interviewer directs the exercise and enables the researcher to analyse the data easily, at the same time allowing the interviewees to express their ideas. Interviews allow clarification of issues and questions asked. The researchers preferred semi structured interviews because a wide range of information was required including perceptions, feelings and behaviours of primary school practical subject teachers and learners.

\section{Population and sample}

Dlamini (2011) argues that a research population is generally a large collection of individuals or objects that is themain focus of a scientific inquiry. Saifert (2007) defines a population as the entire group from which the sample will be drawn. One can therefore say that the population is a group of people or objects which the researcher wishes to observe. The target population for this study was all learners and teachers in grade 5, 6, and 7 in one school in the Hhohho region of Swaziland. Since it was not possible for the researchers to include all these people in the study, the researchers purposively selected six learners, boys and girls, from grade 5, 6 and 7 and 3 teachers from the school. The researchers purposively selected 2 pupils from each grade. The chosen learners were class monitors and therefore believed to be aware of everything happening in class. Class teachers for each grade were also purposively selected and the total number of participants was 9 .

\section{Data collection procedures}

Interviews were used as the main data collection technique. Interview questions were designed to collect information on the teaching of practical subjects in the school. One-on-one interviews were used to solicit information from learners and teachers. Observations were also used to collect and to substantiate the information gathered from the interviews. The researcher observed teachers and learners during teaching and learning of practical subjects. The walls, floors, and corners with finished articles displayed in the classrooms, assessment record books, scheme and plan books as well as learners' exercise books for practical subjects were observed.

\section{Data management and ethical considerations}

The information gathered from the teachers and learners was stored in the researchers' office where no one could have any access to it except the researchers. The researchers did not use the names of the participants but instead numerals from 1-4 were used to refer to the teachers while letters from A-F were used to refer to the learners. This was done to protect the identity of the participants (Cresswell, 2009). Permission to do the study was sought from the principal of the school. Permission to involve minors was sought from parents or their guardians through a consent form that parents/guardians were asked to sign (Cresswell, 2009).

\section{Findings of the study and discussion}

The findings of the study were presented following the themes that emerged from the study. The themes that emerged from the study were namely; practical subjects that are taught in primary schools and their importance, teachers' perceptions about practical subjects, learners' perceptions about practical subjects, incentives given to learners who participate in practical subjects and challenges of teaching practical subjects.

\section{Practical subjects that are taught in primary schools and their importance}

When the teachers were asked how they perceived practical subjects they said that practical subjects were very important because they impact life skills to learners. Teachers therefore felt that it is vital for practical subjects to be taught in schools. When asked to list the practical subjects that they teach in the school the teachers mentioned Home Economics, Practical arts, Agriculture and Physical education. The teachers however stated that they did not teach all the practical subjects but they only taught those that they are comfortable with. What this meant was that despite the availability of the practical subjects that teachers listed, it was not all of them that were taught. The teachers also pointed out that even though they did not teach all the subjects, they 
were however cognisant of their importance. When asked what made them uncomfortable teaching the other practical subjects the teachers' response was that they were not adequately trained to teach them. On when the practical subjects were taught, the teachers' responses were that the practical subjects were time-tabled so they taught them during the allocated time. The teachers' responses on the importance of practical subjects were in line with Backer (1992), Earle (2013), and The Herald (2013)who revealed that the teaching of practical subjects develops a learner holistically for the world of work hence the subjects should be made compulsory.

\section{Teachers' perceptions towards practical subjects}

Teachers felt that the practical subjects make both the teacher and the learners to develop selfconfidence. All the teachers' responses showed that practical subjects are important to learners in many ways. The responses from interviewed teachers on their perceptions on practical subjects revealed that practical subjects are very important because they equip learners with the skills that are needed by the society hence the economy of the country is empowered through the teaching of these subjects. They bring freedom in teaching and learning which makes it to be enjoyable, (Camara, 1997). Through becoming involved in the learning situation and investigating and also in making discoveries for oneself, the learners' sight is widened. Again, learners realise their potential and feel secure in the learning process and their self-concept is strengthened (Giddens, 2006). Lahey (2004) postulates that practical subjects take education as the practice of practise of freedom, as they help the learners to perceive things critically the way they exist. The teachers further said that practical subjects provide a free relaxed teaching /learning atmosphere which is a very important ingredient for effective learning. Teachers who were involved in the research further felt that practical subjects prepare learners for life and help the learners to be critical thinkers. This concurs with what is postulated by Giddens (2006) that practical subjects make education to be the practice of freedom as they enable learners to perceive things critically.

\section{Learners' perceptions about practical subjects}

Learners were also asked to explain how they perceive the learning practical subjects. The responses from all the learners on their perceptions on practical subjects indicated that practical subjects help learners to acquire sufficient skills that enable them to engage in self-reliant and productive work when they leave school and also that these subjects enable learners to be active learners. In line with Taylor (2001)the learners felt that vocational/ practical education is among the vital tools an individual can use to be developed. It is training for useful employment in trade, industries, agriculture, business and home making. According to Taylor (2001)emphasis on vocation or technical education is to prepare one for self-reliance. Getting the opportunity to do things for themselves is in line with Griffiths (2005) who argues that children are good in manipulating the teaching and learning materials practically. Taylor (2001) also postulates that children develop positive discipline when they are part of the teaching and learning process. Learners also pointed out that practical subjects are important because they relieve them from the classroom. They said that the classroom was boring because there it was the teacher who did the talking while they just had to sit and listen. With practical subjects however, they got the opportunity to also do things during the teaching/learning process. While teachers felt that practical subjects should be made compulsory, some learners felt that practical subjects should be optional.

\section{Incentives given to learners who participate in practical subjects}

Teachers and learners were asked what incentives are given to learners to motivate them to like the practical part of the subject. Teacher 1 revealed that," in physical education, learners who have excelled are given certificates at the end of the year speech and prize giving day". Similarly teacher 2revealed that, "learners are given their practical art finished goods to use at home". In line with teacher 2, teacher 3 revealed that, "learners are given their produce to take home. In agriculture whatever they have harvested in their plots, they take home." Similar to teacher 1, the learners said that they are given certificates by the head teacher during the speech and prize giving day which is something that is not done for other subjects. Learner C, D, E, and Frevealed that, they are motivated because they are given the finished products to take it home. This includes all the garden produce as well as chickens and rabbits. Teachers were asked to give the subjects in which most learners participated. Teacher 1 revealed that, “...in physical education, learners enjoy doing the outdoor games than being in class the whole day and those who are shy in class you can hear them shouting when doing practicals than theory." Similar to teacher 1,andteacher 2revealed that, "learners seem to participate more on practicals rather than on theory. They exhibit some unique skills when doing their practicals." In line with teacher 1 and teacher 2, teacher 3revealed that, "...those who are slow learners in the theory part usually excel when it comes to practical subject lessons". The responses from the teachers revealed that, through practical subjects, learners are given a chance to show their unique skills and talents. Practical subjects also increase the regaining of knowledge to learners (Masri, 2000). Through the use of teaching methods like discussions, group work, question and answer, to name a few, amongst learners, there is major gain of knowledge. When the 
participators are mostly involved in the process of teaching and learning, satisfactory knowledge is obtained and their academic work is improved in schools.

\section{Challenges in teaching practical subjects}

Teachers were asked to give the challenges that they faced when teaching practical subjects in the school. Teacher 1 revealed that, "...there is not enough time to prepare for the practicals because I teach all the subjects in the school". Similar to what teacher 1 stated, teacher 2 revealed that, "...sometimes you find that the Head teacher does not buy the materials that we have ordered and we end up teaching just the theory". In line with what teacher 1 andteacher 2 stated, Teacher 3revealed that,“...in agriculture practicals you find that the tools are not enough for the learners to do their work and they end up not finishing in time". The teachers' responses show that lack of enough materials when teaching practical subjects is one of the obstacles that affect the teaching of practical subjects in the schools. Another challenge was the unavailability of infrastructure that was required for teaching practical subjects. This includes laboratories for the different practical subjects. Teachers also stated that they were not adequately trained to teach practical subjects hence they did not feel comfortable having to teach them hence, they taught some and did not teach others.

\section{RESEARCHERS' OBSERVATIONS}

The learner-teacher interaction was not adequate due to the high numbers of learners in class and that led to the instructor concentrating on fast learners while the slow learners were not catered for. The researchers observed that teacher 1 and teacher 3 used all the periods for teaching practical subjects and teacher 2 did not use all the allocated periods in the teaching of practical subject. Instead some of the periods allocated for practical subjects were used to teach other subjects. The researcher also observed that there were not enough materials or equipment to be used in the teaching and learning of practical subjects. This observation confirmed what the teachers had said about inadequate materials and tools. The researchers noted that grade six learners had to wait for others to finish using garden tools before they could use them. The researchers also observed that some teachers used derogatory remarks when reprimanding learners for behaviour that was not acceptable, more especially during the practicals. Teacher 3 used abusive words and referred to learners as' long necks' when reprimanding them. "You long neck, eish! What are you doing now? And the other learners laughed at him. Teacher 1 and teacher 2, however talked nicely to the learners and were always friendly to them "...okay good people let us do it this way, do you all understand?"Such talk created a relaxed atmosphere which made learning conducive. The researchers discovered that teachers did teach practical subjects in the school. The availability of teaching materials on the walls, finished products on the displays showed that practical subjects are taught in the school. However, there were challenges of material resources and limited knowledge in practical subjects amongst the teachers. Some teachers also used derogatory words when talking to the learners and this demotivated them.

\section{DISCUSSION OF FINDINGS}

The study found that the teaching and learning of practical subjects was not effectively done because the school did not have infrastructure needed to conduct the lessons on these subjects. The infrastructure included the laboratories for the practical subjects which are Home Economics, Physical Education, Practical Arts, and Agriculture. The theoretical part of the subjects was taught but the absence of the laboratories made the practicals difficult to do. Teaching materials were also inadequate. The teachers had to do a lot of improvisation to ensure that the practicals were done and at times the practicals were not done at all and this hindered effective learning (Dlamini, 2011).The study also found out that the re-introduction of practical subjects in school starting from the primary up to tertiary level would spur skills development among children which they would use for creating, rather than looking for employment (Lewis, 2006). Teachers felt that practical subjects should be made compulsory for all pupils so that they attain skills that will not make them seek employment. Practical subjects should be encouraged in schools and should be taken seriously as they are the only way the country would develop skilled manpower than the current situation where there are educated people who lack requisite practicals. Earle(2013) and The Herald(2013) advocate for the compulsory inclusion of practical subjects so that learners can be equipped with skills that will make them self-employable. The study also found out that sometimes the teaching and learning of practical subjects is done without the required materials and this makes the teaching ineffective. Another finding was that primary school teachers sign a contract that compels them to teach all subjects in the school. This then compels them to teach subjects that they are not comfortable with which they did not specialize in and this makes their teaching to be ineffective. The data gathered from the learners indicated that learners areless motivated to learn practical subjects because while they get incentives from the school for taking part in practical subjects, some teachers call them names during the practical sessions. It was however very encouraging to note that, some teachers have practical subjects very close to their hearts and they try to motivate the learners to do them. 


\section{CONCLUSIONS}

This study concludes that practical subjects prepare learners not only for the world of work, but for life. The paper also concludes that practical subjects are important in the lives of all students. The paper also concludes that offering practical subjects could help reduce unemployment. The study further concludes that practical subjects are sometimes not effectively taught due to unskilled personnel, and not having enough time for preparations because the teachers in primary schools are to teach all subjects. Lastly the study concludes that practical subjects improvethe learners' academic work by producing self-reliant learners, critical thinkers and they embrace reality and experimentation which teaches the learners to solve problems.

\section{RECOMMENDATIONS}

The study recommends that practical subjects should be made compulsory subjects to all learners in all schools. This study recommends that schools need to be equipped with adequate and relevant human and material resources for teaching practical subjects effectively. The study recommends that learners should be involved in practical work, meaning that learners should be taught the practical subjects to enable them to solve problems in real life situations and also to be self-reliant. It is a recommendation in this study that teachers be appropriately equipped to teach practical subjects through staff development and work-shops so that they can effectively teach these subjects.

\section{REFERENCES}

[1] Backer, J. (1996). Introduction to Vocational Learning: Pretoria: University Press.

[2] Bell, J. (1989). Doing your Research Project: London: Open University Press.

[3] Booth, M.Z. (2004). Culture and Education: the Social consequences of Western Schooling in contemporary Swaziland. New York: University Press of America, Inc.

[4] Brittain, W. (1979). Creativity, Arts, and the Young Child. London: Collier Macmillan Publishers

[5] Chiromo, S. (2000).Research Methods and Statistics in Zimbabwe.Harare: Midlands State University.

[6] Cohen, L. (1989). Research in classroom and school:London: Harper.

[7] Cohen, L. \&Manion, L. (1994). Research Methods in Education: London: Routlege.

[8] Cooke, M. (2001).The Student Aid to Home Economy: Pretoria: Maskew Miller.

[9] Cresswell, J. W. (2009). Research Design: Qualitative, Quantitative, and Mixed Method Approaches (3 ${ }^{\text {rd }}$ Ed.) London: Sage Publications.

[10] Crowther, J. (1995). Oxford Advanced Learners Dictionary. Oxford: Lake Publishers.

[11] Dewey, J. (1982). The Child and the Curriculum: New York: Nicholas Publishing Company.

[12] Dlamini, B.T. (2011). Primary Education Methods: Classroom Management \& Integration Methods. Kwaluseni: University of Swaziland.

[13] Domson-Lindsay A. (2014). South African Swaziland relations: A constructivist reading, South African Journal of International Affairs, Vol. 21, Issue 3, pp. 391-411.

[14] Ducci, M. (1991).Vocational Training: London: McGraw Hill.

[15] Farrant, J. (1993). Theory and Practice of Education: Singapore: Longman.

[16] Gay, A. (1990). Fundamentals of Educational Research: London: Palmer.

[17] Giddens, H. (2006).Research Methods and Statistics in Psychology:London: Rutledge.

[18] Ginindza, A.N. (2006). Significant Parental Involvement in Subject Selection in Schools: An evaluation of their influence on pupils' performance at junior certificate Level in Swaziland. Unpublished thesis, Kwaluseni: UNISWA.

[19] Griffiths, G. (2005). Clinical Teacher Education: New York: Random House.

[20] Haggerty, J. (1999).Food and Nutrition: New York: Manley.

[21] Harbison, D. (2006). Understanding Teachers' Development: London: Cassell.

[22] Imbokodvo National Movement (1972).The Policies and Objectives of the Imbokodvo National Movement.

[23] Jacobs, L.V. (2006).Teaching Practical Arts in Primary School:Netherlands: Wolters-Noordhoff.

[24] Leedy, D. (2001).Practical Research Planning and Design: New York: American University.

[25] Lewis, P.S. (2006). Curriculum Perspectives and Issues: New York: Plenum Press.

[26] Lewis, S. (2005). Promoting Adult Growth in School. Boston: Allyn and Bacon.

[27] Masri, M. (2000). Vocational Education the way ahead: London: Macmillan Press LTD.

[28] Mushoriwa, T.D (2009). Research for Beginners: A Theoretical and Practical Guide to ResearchProject Writing. Manzini: Mandu Printers.

[29] Mushoriwa, T.D (2010). Educational Research: Kwaluseni: University of Swaziland.

[30] Okafor, S. I. (1987). Education for What: Benin: Martin Press. 
[31] Osuala, E .C. (2001). The Importance of Vocational training in the socio-economic of Nigeria: Vocational/Technical Education and manpower development. Pacific Publishers LTD.

[32] Padunmg, L.L (1994).Youth and Vocational/Technical Education in Nigeria, Studies inTechnical Education:Lagos: Zakat Publishers Ltd.

[33] Schumacher, B. (1987). Education for development: London: London Institute of Education.

[34] Taylor, C. (2001). Curriculum Development: London: Oxford University Press.

[35] The National Committee Education Report (1975). Ministry of Education: Kingdom of Swaziland.

[36] The Nation on line Net, (2012). Education Theory vs. Hands on Practicals: National Award for destroying Nigerians practical education? Nigeria, Lagos.

[37] The National Education Review Commission (NERCOM) (1985). Reform through dialogue:Mbabane.

[38] UNESCO, (2006). Road Map of Arts Education; the World Conference on Arts Education,Building Creative Capacities for the $21^{\text {st }}$ Century. Lisbon: Westview Press.

[39] Waithera, K.S. (2013). Challenges to teaching and Learning of Agriculture in secondary schools in Kakuyuni Division:Kangundo District Machakos country, Kenya, Unpublished M.ed Thesis, Kenyatta University.

[40] Warni, I.J. (2014). Challenges facing teaching and Learning of business studies in a day secondary schools in Kiringara West Disrict, Kirinyaga country, unpublished M.ed Thesis, Kenyatta, University. 